\title{
Tissue-specific regulation of acetyl-CoA carboxylase gene expression by dietary soya protein isolate in rats
}

\author{
Chao Wu Xiao ${ }^{1,2 *}$, Carla Wood ${ }^{1}$, Wenxin Huang ${ }^{1}$, Mary R. L’Abbé ${ }^{1}$, G. Sarwar Gilani ${ }^{1}$, Gerard M. Cooke ${ }^{2,3}$ \\ and Ivan Curran ${ }^{3}$ \\ ${ }^{1}$ Nutrition Research Division, Food Directorate, Health Products and Food Branch, Health Canada, 2203C Banting Research \\ Centre, Ottawa, ON, Canada K1A OL2 \\ ${ }^{2}$ Department of Cellular and Molecular Medicine, Faculty of Medicine, University of Ottawa, Ottawa, ON, Canada KIH 8M5 \\ ${ }^{3}$ Toxicology Research Division, Food Directorate, Health Products and Food Branch, Health Canada, 2203C Banting Research \\ Centre, Ottawa, ON, Canada K1A OL2
}

(Received 23 September 2005 - Revised 16 January 2006 - Accepted 8 February 2006)

\begin{abstract}
We have recently reported that intake of soya protein isolate (SPI) inhibited the DNA-binding activities of hepatic thyroid hormone receptor (TR). The genes for acetyl-CoA carboxylase (ACC), a rate-limiting enzyme in fatty acid synthesis, contain the thyroid hormone response element in their promoters and are regulated by TR. The present study has examined the effect of long-term feeding of SPI and soya isoflavones (ISF) on the gene expression and protein phosphorylation of different ACC isoforms in different tissues and plasma triacylglycerol (TAG) levels in rats. SpragueDawley female rats were fed diets containing $20 \%$ casein or alcohol-washed SPI with or without supplemental ISF for 70, 190 and $310 \mathrm{~d}$. SPI intake significantly reduced plasma TAG concentrations compared with casein, whereas supplemental ISF had no effect. Hepatic ACC $\alpha$ and ACC $\beta$ mRNA abundance and protein content were markedly lower in the rats fed SPI than in those fed casein. The protein contents of ACC $\alpha$ in the kidney and $\mathrm{ACC} \beta$, the predominant isoform in the heart and kidney, were unchanged by dietary SPI. The ratios of phospho-ACC $\alpha /$ ACC $\alpha$ and phospho-ACC $\beta / A C C \beta$ were not different among dietary groups in all tissues measured. The present study demonstrates that ingestion of SPI decreases plasma TAG level and down-regulates ACC $\alpha$ and ACC $\beta$ gene expression in the liver but not in the heart and kidney. The results indicate that the effect of SPI is tissue-specific and that alteration of ACC gene expression rather than phosphorylation status may play a major role in the regulation of ACC activities by soya proteins.
\end{abstract}

Rats: Soya protein isolate: Acetyl-CoA carboxylase gene: Triacylglycerol

The blood triacylglycerol (TAG) level is one of the important risk factors for chronic diseases such as CVD, type 2 diabetes and atherosclerosis. In particular, high plasma TAG levels in women are better predictors of CVD risk than total or LDL-cholesterol (Cullen, 2000; Meagher, 2004).

Soya consumption has been associated with a decreased risk of CVD, type 2 diabetes and atherosclerosis (Anderson et al. 1995; Potter, 1998; Hermansen et al. 2001). These beneficial effects of soya appear to be, at least partially, due to its hypotriacylglycerolaemic actions. Soya diets decreased the blood TAG level in both animals (Lin et al. 2004; Moriyama et al. 2004; Ascencio et al. 2004) and hyperlipidaemic human subjects (Wang et al. 2004). The hypotriacylglycerolaemic action of soya components is believed to be a consequence of decreased biosynthesis and enhanced degradation of fatty acids.

Acetyl-CoA carboxylase (ACC) is a rate-limiting enzyme that catalyses the carboxylation of acetyl-CoA to form malonyl-CoA, the first step in the pathway of long-chain fatty acid biosynthesis (Wakil et al. 1983). Two isoforms of ACC have been identified. $\mathrm{ACC} \alpha$ is a cytosolic protein and highly expressed in liver and adipose tissue, whereas ACC $\beta$ is located in mitochondria and is predominantly expressed in heart and muscle, and to a lesser extent in liver. ACC $\beta$ plays a pivotal role in the regulation of mitochondrial fatty acid $\beta$-oxidation (Hillgartner et al. 1996) through feedback inhibition of carnitine palmitoyltransferase-1, an enzyme that controls the entry of long-chain fatty acid CoA esters into the mitochondria for degradation (Abu-Elheiga et al. 2000). Suppression of ACC $\beta$ increases carnitine palmitoyltransferase- 1 activity and enhances fatty acid $\beta$-oxidation. ACC activity in different tissues is regulated differently. For instance, ACC $\beta$ activity in skeletal muscle is mainly regulated by phosphorylation and dephosphorylation (Dyck et al. 1999; Minokoshi et al. 2002), whereas the hepatic ACC $\beta$ activity is regulated at the transcriptional level (Harwood et al. 2003; Oh et al. 2003).

Thyroid hormones play an important role in the regulation of lipid metabolism. Our previous studies showed that

Abbreviations: ACC, acetyl-CoA carboxylase; ISF, isoflavones; pACC, phospho-ACC; SPI, soya protein isolate; TAG, triacylglycerol; TR, thyroid hormone receptor.

* Corresponding author: Dr Chao Wu Xiao, fax +1 613941 6182, email chaowu_xiao@hc-sc.gc.ca 
consumption of soya protein isolate (SPI) increased hepatic thyroid hormone receptor (TR) $\beta 1$ protein content and inhibited the binding activities of hepatic nuclear TR to its target genes in rats (Xiao et al. 2004; Huang et al. 2005). These cellular responses of TR to dietary SPI are believed to affect thyroid hormone functions and alter the downstream gene expression. The ACC $\alpha$ gene contains thyroid hormone response elements in its promoter regions (Huang \& Freake, 1998), and is regulated by thyroid hormones in a tissuespecific manner (Blennemann et al. 1995; Huang \& Freake, 1998). Although soya protein intake was shown to suppress the enzymatic activity of ACC in rat liver (Iritani et al. 1986), the regulation of the gene expression for different ACC isoforms ( $\alpha$ and $\beta$ ) in different tissues by dietary soya components are not fully understood.

The objective of the present study was to determine the effect of dietary soya proteins and soya-derived ISF on plasma TAG levels as well as ACC $\alpha$ and ACC $\beta$ phosphorylation and gene expression in different tissues of rats.

\section{Materials and methods}

\section{Chemicals and reagents}

Alcohol-washed SPI (Pro Fam 930) and Novasoy soya ISF concentrate were purchased from Archer Daniels Midland Company (Decatur, IL, USA). Casein protein (90\% total protein) was from ICN Biomedicals (Cleveland, $\mathrm{OH}$, USA). Agarose, Tris and phenylmethylsulphonyl fluoride were from Sigma Chemical (St. Louis, MO, USA). ECL Western blotting detection kit was obtained from Amersham (Arlington Heights, IL, USA). Nitrocellulose membranes, acrylamide, $\mathrm{N}, \quad \mathrm{N}^{\prime}$-methylene-bis-acrylamide, ammonium persulphate, dithiothreitol, glycine, goat anti-rabbit $\mathrm{IgG}$ $(\mathrm{H}+\mathrm{L})$-horseradish peroxidase conjugated antibody, goat anti-mouse $\operatorname{IgG}(\mathrm{H}+\mathrm{L})$-horseradish peroxidase conjugated antibody and Bio-Rad protein assay kit were purchased from Bio-Rad Laboratories (Hercules, CA, USA). X-ray film was from MJS Biolynx (Brockville, ON, Canada). Rabbit polyclonal anti-rat phospho-ACC (pACC; Ser79) and anti-human ACC $\alpha$ and ACC $\beta$ antibodies that crossreact with rat proteins were purchased from Upstate (Lake Placid, NY, USA). TRIzol reagent and M-MLV RT were from Invitrogen Canada Inc. (Burlington, ON, Canada). Taq DNA polymerase was purchased from New England Biolabs (Beverly, MA, USA). QuantumRNA 18S internal standards were purchased from Ambion (Austin, TX, USA). Reagents for TAG quantitation in plasma were from Wako Chemicals (Richmond, VA, USA). Mouse leptin ELISA kits were from Crystal Chem (Downers Grove, IL, USA) and ultrasensitive rat insulin ELISA kits were purchased from ALPCO Diagnostics (Windham, NH, USA).

\section{Animals and diets}

Animal experimental protocols were approved by the Health Canada Animal Care Committee and all animal handling and care followed the guidelines of the Canadian Council for Animal Care. Pubertal Sprague-Dawley rats (Charles River, St. Constant, PQ, Canada) were pair housed in stainless steel cages and randomly allotted into three groups (thirty-five females per group), and kept in an environmentally controlled room with a $12 \mathrm{~h}$ light-dark cycle. After acclimation, starting at $50 \mathrm{~d}$ of age, rats were given free access to one of the three diets (Table 1) and tap water before being killed. All diets were formulated according to the specifications of AIN93G (Reeves et al. 1993) except that in diets 2 and 3, casein was replaced by alcohol-washed SPI (Pro Fam 930). In addition, diet 3 was supplemented with ISF $(250 \mathrm{mg} / \mathrm{kg}$ diet; Novasoy ISF concentrate). Body weights and food consumption were recorded weekly. The actual content of ISF including genistein, daidzein and glycitein was determined by Waters HPLC linear gradient with UV detection monitored at $254 \mathrm{~nm}$ (Wang \& Murphy, 1994) and is shown in Table 1. After being fed for 70, 190 and $310 \mathrm{~d}$, ten rats from each diet group were killed by exsanguination through cardiac puncture under general anaesthesia with isoflurane, and the tissues were collected, immediately frozen in liquid $\mathrm{N}$ and stored at $-80^{\circ} \mathrm{C}$ until analysis.

\section{Plasma triacylglycerol, insulin and leptin}

Plasma TAG concentrations were measured using a microplate enzymatic colorimetric method (Wako Chemicals). Briefly, plasma $(5 \mu \mathrm{l})$ was added to microtitre plate wells and incubated with $80 \mu \mathrm{l}$ Enzyme Color A for $5 \mathrm{~min}$ to decompose free glycerol. Subsequently, $40 \mu \mathrm{l}$ Enzyme Color B was added and incubated for $5 \mathrm{~min}$. The absorbance was read at $595 \mathrm{~nm}$ in a microplate reader (Model 3550-UV; Bio-Rad). The TAG concentrations were calculated using the standard curves. Plasma insulin and leptin concentrations were determined using double-antibody sandwich enzyme immunoassay according to the manufacturer's instructions.

Table 1. Composition of experimental diets ( $\mathrm{g} / \mathrm{kg}$ diet)

\begin{tabular}{|c|c|c|c|}
\hline Ingredient & Casein & SPI & $\mathrm{SPI}+\mathrm{ISF}$ \\
\hline Casein* & $222 \cdot 2$ & - & - \\
\hline Soya protein† & - & $222 \cdot 2$ & $222 \cdot 2$ \\
\hline Sucrose & $100 \cdot 0$ & $100 \cdot 0$ & $100 \cdot 0$ \\
\hline Maizestarch & $375 \cdot 3$ & $375 \cdot 3$ & 374.5 \\
\hline Dextronized Maizestarch & $132 \cdot 0$ & $132 \cdot 0$ & $132 \cdot 0$ \\
\hline Soyabean oil & $70 \cdot 0$ & $70 \cdot 0$ & $70 \cdot 0$ \\
\hline Cellulose & $50 \cdot 0$ & $50 \cdot 0$ & $50 \cdot 0$ \\
\hline Mineral mix $\ddagger$ & $35 \cdot 0$ & $35 \cdot 0$ & $35 \cdot 0$ \\
\hline Vitamin mix & $10 \cdot 0$ & $10 \cdot 0$ & $10 \cdot 0$ \\
\hline Choline bitartrate & $2 \cdot 5$ & 2.5 & $2 \cdot 5$ \\
\hline L-Cystine & $3 \cdot 0$ & - & - \\
\hline L-Methionine & - & $3 \cdot 0$ & $3 \cdot 0$ \\
\hline tert-Butylhydroquinone & 0.014 & 0.014 & 0.014 \\
\hline Novasoya & - & - & 0.833 \\
\hline Total isoflavones (mg/kg diet)§ & 0.0 & $31 \cdot 7$ & $235 \cdot 6$ \\
\hline Genistein (mg/kg diet)§ & ND & $18 \cdot 6$ & 124.4 \\
\hline Daidzein (mg/kg diet)§ & ND & $10 \cdot 5$ & 90.9 \\
\hline Glycitein (mg/kg diet)§ & ND & $2 \cdot 6$ & $20 \cdot 5$ \\
\hline
\end{tabular}

ISF, isoflavones; ND, not detectable; SPI, soya protein isolate.

${ }^{*}$ Casein from ICN Biomedicals contains $90 \%$ crude protein.

†Alcohol-washed SPI contains $90 \%$ crude protein, and Novasoy ISF concentrate contains $30 \%$ total ISF.

$\ddagger$ AIN-93G Mineral mix and AIN-93G Vitamin mix were from ICN Biomedicals.

$\S$ The actual content of ISF (genistein, daidzein and glycitein) was determined by Waters HPLC linear gradient with UV detection monitored at $254 \mathrm{~nm}$. 
Protein extraction and Western blot analysis of acetyl-CoA carboxylase and phospho-acetyl-CoA carboxylase

Total protein preparation and ACC analyses were carried out as recommended by Upstate with minor modifications. Briefly, rat tissues were homogenized in lysis buffer with a glass homogenizer and then sonicated three times for $30 \mathrm{~s}$ on ice. The homogenate was centrifuged to separate the cell debris, and the protein content of the extracts was determined. Total proteins $(80 \mu \mathrm{g})$ were mixed with loading buffer and incubated at $37^{\circ} \mathrm{C}$ for $30 \mathrm{~min}$ before they were separated in $6 \% \mathrm{SDS}-\mathrm{PAGE}$. The resolved proteins were electrotransferred $(30 \mathrm{~V}$, overnight) on to nitrocellulose membranes. The blots were immunostained with ACC or pACC antibodies and the immunoreactivity was detected using the ECL kit. The intensities of $\mathrm{ACC} \alpha, \mathrm{ACC} \beta, \mathrm{pACC} \alpha$ and $\mathrm{pACC} \beta$ protein bands were measured densitometrically using Scion Image (Scion Corporation, Frederick, MD, USA), and normalized by the respective Ponceau-stained total protein (Xiao et al. 2003). The ratios of pACC $\alpha$ :ACC $\alpha$ and pACC$\beta: A C C \beta$ were calculated. The specificities of these antibodies were confirmed using their respective blocking peptides.

Quantitation of hepatic acetyl-CoA carboxylase $\alpha$ and acetylCoA carboxylase $\beta$ mRNA abundances

Total RNA was isolated from rat liver samples with TRIzol reagent according to the manufacturer's instructions. Total RNA (500 ng) was reverse transcribed for cDNA synthesis. One-tenth of the cDNA synthesized was then amplified with the following primers: rat ACC $\alpha$ [forward: 5'-CTTTCACATGAGGTCCAGCA-3' (213-232), reverse: 5'-ACTCGAAGACCACTGCCACT-3' (797-778)]; rat ACC $\beta$ [forward: 5'-CCTGTAGATGCCAGTCAGCA-3' (232-251), reverse: 5'- GACATGCTGGGCCTCATAGT-3' (653-634)] and universal 18S rRNA primers and competimers (Ambion) in a ratio of 4:6 for ACC $\alpha$ or 3.5:6.5 for ACC $\beta$. PCR cycle conditions were $94^{\circ} \mathrm{C}$ for $5 \mathrm{~min}, 94^{\circ} \mathrm{C}$ for $45 \mathrm{~s}, 60^{\circ} \mathrm{C}$ for $45 \mathrm{~s}$ and $72^{\circ} \mathrm{C}$ for $45 \mathrm{~s}, 72^{\circ} \mathrm{C}$ for $10 \mathrm{~min}$. Amplification cycle numbers were twenty-six for ACC $\alpha$ and thirty-two for ACC $\beta$. Samples were resolved on $2 \%$ agarose gels and visualized with SYBR Green. ACC $\alpha$ and ACC $\beta$ mRNA levels were normalized against their respective $18 \mathrm{~S}$ rRNA content.

\section{Statistical analyses}

Results are expressed as means with their standard errors. Effects of treatment on plasma insulin, leptin, TAG concentrations and mRNA or protein contents of $\mathrm{ACC} \alpha$ and $\mathrm{ACC} \beta$, as well as the ratios of $\mathrm{pACC} \alpha: \mathrm{ACC} \alpha$ and pACC $\beta$ :ACC $\beta$ were analysed using two-way ANOVA, which included the main effects of diet and feeding period as well as the interactions of diet $\times$ feeding period. The dietary effects on food consumption, body and liver weights were analysed by one-way ANOVA. Differences between individual means were determined by Fisher's least significant difference test. Dietary effects on renal or cardiac ACC $\alpha$ and ACC $\beta$ protein contents and the ratios of pACC $\alpha: A C C \alpha$ or pACC $\beta$ :ACC $\beta$ were assessed by $t$ test. A probability of $\mathrm{P}<0.05$ was considered to be statistically significant. Data were analysed using Statistica version 7.1 (StatSoft, Tulsa, OK, USA).

\section{Results}

Food consumption, body and liver weights

Food consumption, body and liver weights did not differ among the dietary groups $(P>0 \cdot 05$, data not shown), demonstrating the nutritional adequacy of the test diets.

\section{Plasma triacylglycerol concentration}

Plasma TAG concentrations in the rats fed the casein diet increased with age, whereas the rats fed the diets containing SPI for 70, 190 and $310 \mathrm{~d}$ had significantly lower TAG levels than those fed the casein-based diet. However, the TAG levels in rats fed SPI or SPI + ISF were not different (Fig. 1).

Hepatic acetyl-CoA carboxylase $\alpha$ and acetyl-CoA carboxylase $\beta$ mRNA steady-state level and protein content. Hepatic ACC $\alpha$ and ACC $\beta$ mRNA abundances and protein contents in the rats fed the diet containing SPI for 70,190 and $310 \mathrm{~d}$ were significantly lower than those fed casein-based diet (Figs 2 and 3(a)). Supplemental ISF had no additional effect on either ACC $\alpha$ or ACC $\beta$ protein content (Fig. 3(a)).

Tissue-specific regulation of acetyl-CoA carboxylase $\alpha$ and acetyl-CoA carboxylase $\beta$ expression

ACC $\beta$ protein was detected in all the tissues measured, and its expression was higher in the liver and heart but was very low in the kidney. ACC $\alpha$ protein was detectable by Western blot only in the liver and kidney but not in the heart. Dietary SPI significantly decreased both ACC $\alpha$ and ACC $\beta$ protein contents in the liver, but had no effect on ACC $\alpha$ and $A C C \beta$ in the heart or kidney (Fig. 4(a)).

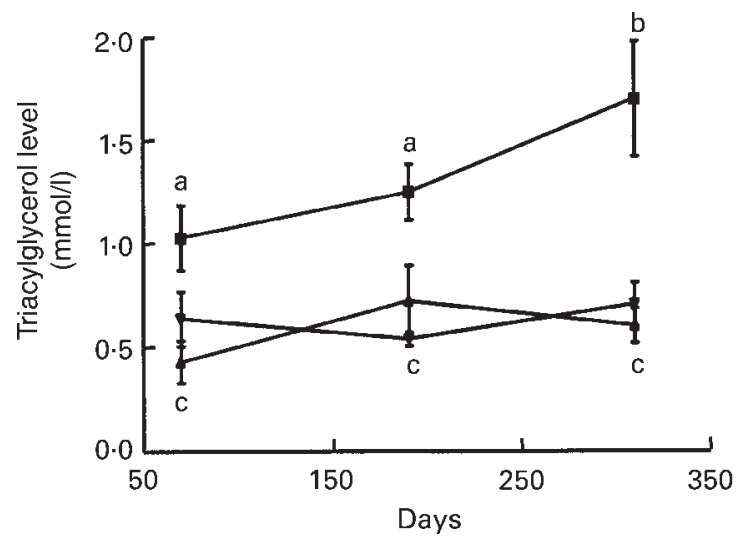

Fig. 1. Plasma triacylglycerol concentrations in rats fed diets containing either casein $(\mathbf{\square})$ or alcohol-washed soya protein isolate in the absence $(\mathbf{\Delta})$ or presence $(\boldsymbol{\nabla})$ of supplemental isoflavones $(250 \mathrm{mg} / \mathrm{kg}$ diet $)$ for 70,190 and $310 \mathrm{~d}$. For details of diets and procedures, see Table 1 and p. 1049. Values are means with their standard errors depicted by vertical bars $(n 6)$. $\mathrm{a}, \mathrm{b}, \mathrm{c}$ Mean values with unlike letters were significantly different $(P<0.05)$. 
(a)

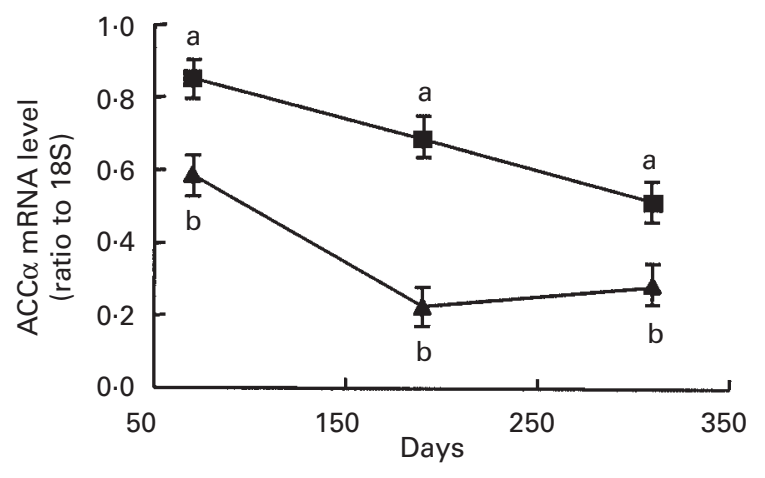

(b)

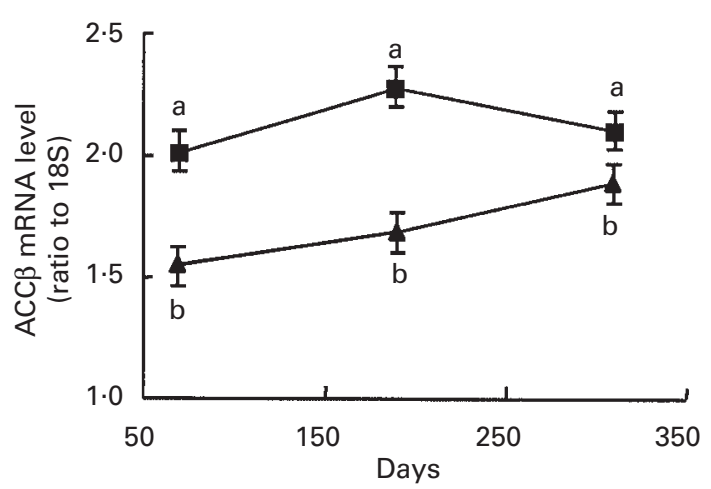

Fig. 2. Hepatic acetyl-CoA carboxylase (ACC) $\alpha$ and ACC $\beta$ mRNA abundances in the rats fed diets containing casein ( $\mathbf{\square}$ ) or alcohol-washed soya protein isolate $(\mathbf{\Delta})$ for 70,190 and $310 \mathrm{~d}$. For details of diets and procedures, see Table 1 and p. 1049. Values are means with their standard errors depicted by vertical bars $(n 6) .{ }^{a, b}$ Mean values with unlike letters were significantly different $(P<0.05)$.

\section{Acetyl-CoA carboxylase $\alpha$ and acetyl-CoA carboxylase $\beta$ phosphorylation}

Both hepatic pACC $\alpha$ and pACC $\beta$ contents in the rats fed SPIbased diets were significantly lower than those fed the casein diet, and showed the same pattern as their total ACC $\alpha$ and ACC $\beta$ proteins (Fig. 3(b)). However, the ratios of $\mathrm{pACC} \alpha: \mathrm{ACC} \alpha$ and pACC $\beta: A C C \beta$ in the liver (Fig. 3(b)), heart and kidney (Fig. 4(b)) were not different among dietary groups except that supplemental ISF increased the pACC $\alpha: A C C \alpha$ ratio in the rats fed for $70 \mathrm{~d}$ (Fig. 3(b)).

\section{Plasma insulin and leptin concentrations}

Dietary effects on plasma insulin concentration were not significant at all three time-points examined. However, the insulin levels in the rats fed SPI diet alone for 190 or $310 \mathrm{~d}$ were markedly higher than those fed the same diet for $70 \mathrm{~d}$ (Table 2). The rats fed diets containing casein or SPI alone for $310 \mathrm{~d}$ had significantly higher plasma leptin concentrations than those fed the same diets for 70 or $190 \mathrm{~d}$ $(P<0 \cdot 01)$. However, the dietary effect was not significant (Table 2).

\section{Discussion}

The tissue samples analysed in the present study actually were from a part of the multigeneration study as described previously (Xiao et al. 2004). The TR protein content and plasma thyroid hormone (triiodothyronine and thyroxine) levels of these animals were measured and reported (Xiao et al. 2004). In the present study, we have shown that ingestion of soya proteins remarkably decreased plasma TAG concentrations in female rats compared with a casein diet, regardless of the presence of added ISF. This is consistent with previous studies showing that soya proteins rather than ISF play major roles in lowering blood TAG levels (Greaves et al. 1999; Gardner et al. 2001; Fukui et al. 2004b). This concept is further supported by recent studies in healthy post-menopausal women in which soya ISF were shown to have no effect on serum TAG level (Cheng et al. 2004; Colacurci et al. 2005). Although the components responsible for hypotriglycerolaemic actions of soyabeans have not been confirmed, increasing evidence suggests that $\beta$-conglycinin, the major $7 \mathrm{~S}$ soyabean globulin, may contain the bioactive fraction since intake of $\beta$-conglycinin reduced serum TAG level in mice (Moriyama et al. 2004), rats (Aoyama et al. 2001; Duranti et al. 2004; Fukui et al. 2004a) and young women (Baba et al. 2004). Furthermore, the $\alpha^{\prime}$ subunit of $\beta$-conglycinin was shown to be hypotriacylglycerolaemic and as effective as the whole proteins (Duranti et al. 2004).

ACC is a rate-limiting enzyme in the long-chain fatty acid biosynthesis. The results of the present study have demonstrated that both $\mathrm{ACC} \alpha$ and ACC $\beta$ mRNA and protein expression in the liver were significantly reduced by dietary SPI, regardless of the presence of supplemental ISF. However, dietary SPI had no effect on ACC $\alpha$ and ACC $\beta$ protein contents in both kidney and heart, suggesting tissue specificity of the soya effect. This appears to be consistent with our recent observations that dietary SPI elevated TR protein content and suppressed its DNA binding activity in rat livers, but not in the other tissues (Xiao et al. 2004; Huang et al. 2005). Since the liver is a key organ for fatty acid synthesis, and plays pivotal roles in the regulation of blood TAG levels, down-regulation of hepatic ACC $\alpha$ and ACC $\beta$ expression may contribute, at least in part, to the hypotriacylglycerolaemic actions of SPI.

It has been suggested that modulation of insulin levels by soya components might play a role in the regulation of lipogenic gene expression because ingestion of soya proteins in the presence of ISF $(410-456 \mathrm{mg} / \mathrm{kg}$ diet) (Tovar et al. 2002; Ascencio et al. 2004) or soyabean $\beta$-conglycinin (Moriyama et al. 2004) decreased serum insulin levels compared with casein. Administration of insulin up-regulated ACC $\alpha$ mRNA expression and stimulated ACC enzymatic activity in rat liver (Katsurada et al. 1990). However, discrepancies exist in this regard. For example, a recent human study showed that soya ISF markedly reduced blood glucose and insulin levels, but had no effect on serum TAG levels (Cheng et al. 2004). In addition, although plasma and liver TAG levels were significantly lowered by soya proteins in both lean and fatty rats, plasma insulin concentrations were either unaffected in lean rats or even markedly increased in fatty rats (Iritani et al. 1996). In the present study, plasma 
(a)
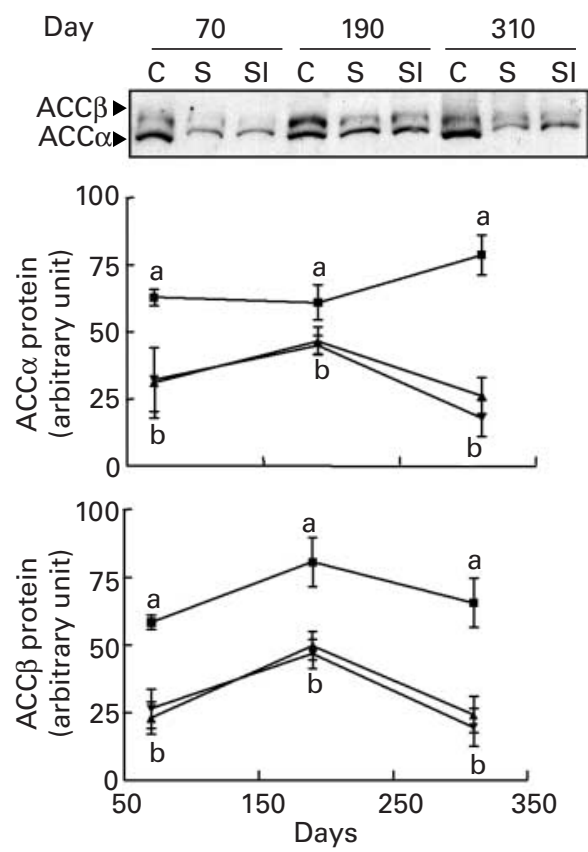

(b)
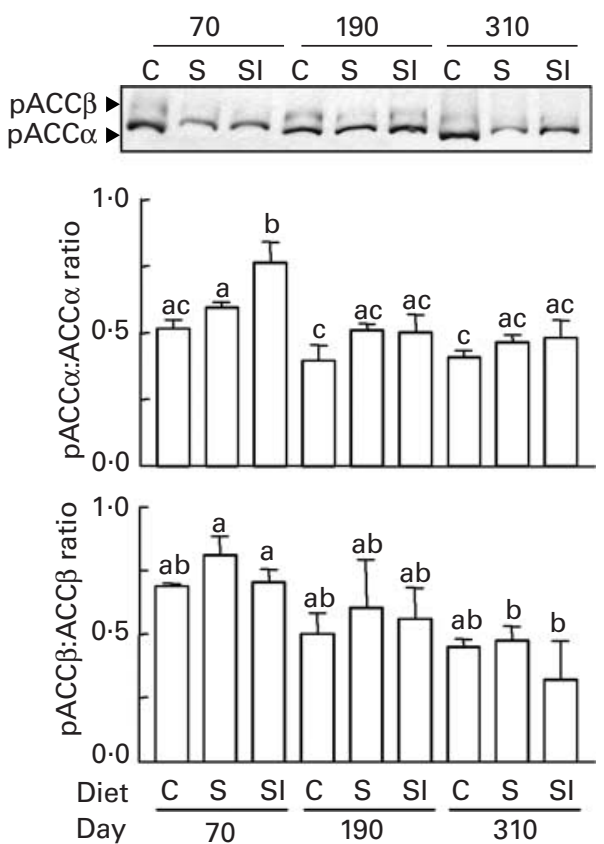

Fig. 3. Acetyl-CoA carboxylase (ACC) $\alpha$ and $A C C \beta$ protein contents (a) and the ratios of phospho-ACC $\alpha$ (pACC $\alpha$ ):ACC $\alpha$ and phospho-ACC $\beta$ (pACC $\beta$ ):ACC $\beta$ (b) in the livers of rats fed diets containing casein $(C, \mathbf{\square})$ or alcohol-washed soya protein isolate in the absence $(\mathrm{S}, \mathbf{\Lambda})$ or presence (SI, $\mathbf{\nabla})$ of supplemental isoflavones $(250 \mathrm{mg} / \mathrm{kg}$ diet) for 70,190 and $310 \mathrm{~d}$. The images shown are representatives of three replicates. For details of diets and procedures, see Table 1 and $\mathrm{p}$. 1049 . Values are means with their standard errors depicted by vertical bars $(n 3) .{ }^{\text {a,b,c }}$ Mean values with unlike letters at the same time-point were significantly different $(P<0.05)$.

insulin levels were not affected by either SPI or added ISF, which is supported by a recent study in fatty rats (Tovar et al. 2005). Taken together, all these findings suggest that decreased insulin levels might not be the only mechanism involved in the hypotriacylglycerolaemic actions of soya proteins.

We have recently suggested that modulation of hepatic TR may play important roles in the mediation of hypolipidaemic actions of soya through alteration of gene expression of key enzymes involved in lipogenesis. We demonstrated that dietary SPI remarkably inhibited the binding ability of hepatic nuclear TR to their target genes (Huang et al. 2005), which would include such lipogenic enzymes as malic enzyme (Petty et al. 1990), fatty acid synthase (Xiong et al. 1998) and ACC (Zhang et al. 2001) since these genes possess thyroid hormone response elements in their promoter regions. Furthermore, triiodothyronine stimulates ACC $\alpha$ mRNA expression and elevates ACC enzymatic activity in rat livers (Katsurada et al. 1990). Although thyroid hormone (triiodothyronine and thyroxine) levels from these animals were unchanged by dietary SPI as reported previously (Xiao et al. 2004), inhibition of TR function could block the stimulatory effect of thyroid hormones on downstream gene expression such as for ACC.

Intake of soya proteins was reported to reduce ACC enzymatic activity in rat liver (Iritani et al. 1986). It is known that ACC activity is mainly regulated by its phosphorylation status rather than altered enzyme content in certain tissues such as skeletal muscle (Dyck et al. 1999; Minokoshi et al. 2002). Whether dietary SPI and ISF influence ACC phosphorylation is unclear. We showed that the phosphorylation and dephosphorylation rates at Ser79 of both ACC $\alpha$ and ACC $\beta$ proteins were not different among dietary groups in all tissues measured, indicating that dietary SPI may regulate ACC mainly through modulation of its protein content rather than phosphorylation or dephosphorylation.

Leptin is a protein secreted by adipose tissues and stimulates oxidation of fatty acids by suppressing ACC activity (Minokoshi et al. 2002). Ingestion of soyabean $\beta$-conglycinin reduced the leptin levels in obese mice (Moriyama et al. 2004). However, the plasma leptin concentration was not affected by dietary SPI or ISF in the present study, which is consistent with the results obtained from previous studies in rats (Ascencio et al. 2004) and in pre- and post-menopausal women (Phipps et al. 2001). This excludes the possible involvement of leptin in the modulation of TAG levels and ACC expression by dietary SPI in the present study.

In summary, the present results show for the first time that consumption of $20 \%$ alcohol-washed SPI suppressed hepatic ACC $\beta$ gene expression. In addition, dietary SPI lowered the plasma TAG level and reduced ACC $\alpha$ mRNA and protein contents in liver, but had no effect in both kidney and heart compared with a casein diet. Furthermore, supplemental ISF had no effect. The ratios of pACC $\alpha: A C C \alpha$ and pACC$\beta: A C C \beta$ were unchanged by SPI. This suggests that regulation of ACC by dietary SPI is mainly through alteration of its gene expression rather than phosphorylation or dephosphorylation. The potential involvement of TR function modification by SPI in the regulation of ACC gene expression and TAG levels is under investigation. 
(a)
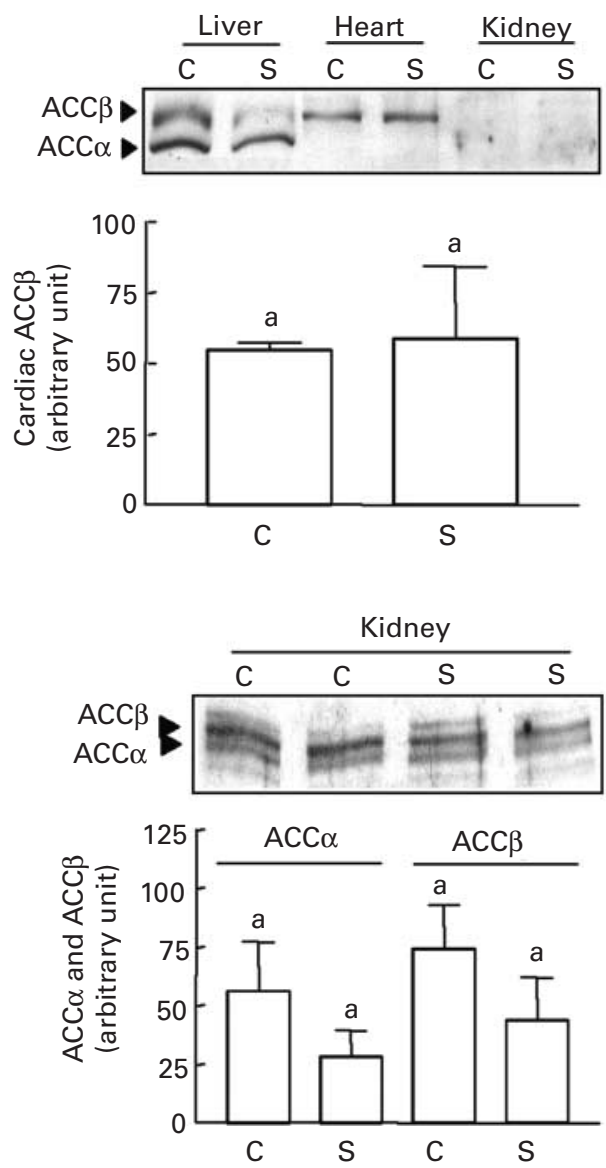

(b)
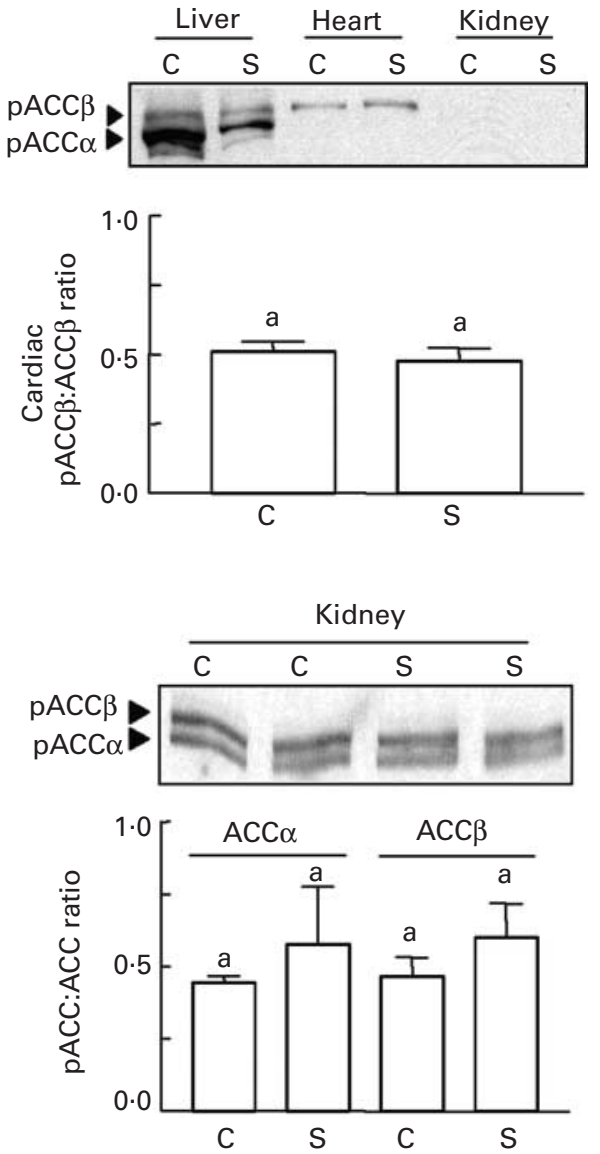

Fig. 4. Acetyl-CoA carboxylase (ACC) $\alpha$ and $A C C \beta$ protein contents and the ratios of phospho-ACC $\alpha$ (pACC $\alpha$ ):ACC $\alpha$ and phospho-ACC $\beta$ (pACC $\beta$ ):ACC $\beta$ in the heart (a) and kidney (b) of the rats fed diets containing casein $(C)$ or alcohol-washed soya protein isolate (S) for $310 \mathrm{~d}$. The images shown are representatives of three replicates. Expression of $A C C \alpha$ and $A C C \beta$ was extremely low in kidney, and the images shown were obtained after extended exposure of the film (b). For details of diets and procedures, see Table 1 and p. 1049. Values are means with their standard errors depicted by vertical bars $(n 6)$. ${ }^{\text {a }}$ Mean values with unlike letters were significantly different $(P<0.05)$.

Table 2. Plasma insulin and leptin concentrations in rats fed diets containing either casein or alcohol-washed soya protein isolate (SPI) for different periods $(\mathrm{pmol} / \mathrm{l})^{*}$

(Mean values with their standard errors; $n 6$ )

\begin{tabular}{|c|c|c|c|c|c|c|}
\hline \multirow[b]{2}{*}{ Days $†$} & \multicolumn{2}{|c|}{ Casein } & \multicolumn{2}{|c|}{ SPI } & \multicolumn{2}{|c|}{ SPI + ISF } \\
\hline & Mean & SEM & Mean & SEM & Mean & SEM \\
\hline \multicolumn{7}{|l|}{ Insulin } \\
\hline 70 & $259 \cdot 5^{a b}$ & $54 \cdot 6$ & $149 \cdot 2^{a}$ & $42 \cdot 1$ & $270 \cdot 3^{a b}$ & $56 \cdot 7$ \\
\hline 190 & $325 \cdot 4^{b}$ & $86 \cdot 7$ & $312 \cdot 3^{b}$ & $42 \cdot 4$ & $303 \cdot 0^{\mathrm{b}}$ & $69 \cdot 8$ \\
\hline 310 & $269 \cdot 1^{b}$ & $47 \cdot 0$ & $353.6^{b}$ & 51.9 & $355 \cdot 8^{b}$ & $92 \cdot 0$ \\
\hline \multicolumn{7}{|l|}{ Leptin } \\
\hline 70 & $174 \cdot 8^{a}$ & $42 \cdot 0$ & $115 \cdot 6^{\mathrm{a}}$ & $42 \cdot 3$ & $137 \cdot 2^{\mathrm{a}}$ & $19 \cdot 4$ \\
\hline 190 & $197 \cdot 0^{a}$ & $26 \cdot 6$ & $216 \cdot 8^{a}$ & $18 \cdot 5$ & $194 \cdot 8^{a}$ & 31.0 \\
\hline 310 & $316 \cdot 0^{\mathrm{b}}$ & $57 \cdot 2$ & $277 \cdot 2^{\mathrm{b}}$ & $56 \cdot 0$ & $241 \cdot 5^{\mathrm{ab}}$ & $35 \cdot 0$ \\
\hline
\end{tabular}

ISF, isoflavones.

a,b Mean values within a row or column with unlike superscript letters were significantly different $(P<0.05)$.

${ }^{*}$ For details of procedures, see p. 1049.

†Days of feeding the experimental diets.

‡Alcohol-washed SPI supplemented with $250 \mathrm{mg} I S F / \mathrm{kg}$ diet.

\section{Acknowledgements}

This is publication no. 606 of the Bureau of Nutritional Sciences. The research was supported by Health Canada.

\section{References}

Abu-Elheiga L, Brinkley WR, Zhong L, Chirala SS, Woldegiorgis G \& Wakil SJ (2000) The subcellular localization of acetyl-CoA carboxylase 2. Proc Natl Acad Sci U S A 97, 1444-1449.

Anderson JW, Johnstone BM \& Cook N (1995) Meta-analysis of the effects of soy protein intake on serum lipids. N Engl J Med 333, $276-282$.

Aoyama T, Kohno M, Saito T, Fukui K, Takamatsu K, Yamamoto T, Hashimoto Y, Hirotsuka M \& Kito M (2001) Reduction by phytate-reduced soybean beta-conglycinin of plasma triglyceride level of young and adult rats. Biosci Biotechnol Biochem 65, $1071-1075$.

Ascencio C, Torres N, Isoard-Acosta F, Gomez-Perez FJ, HernandezPando R \& Tovar AR (2004) Soy protein affects serum insulin and hepatic SREBP-1 mRNA and reduces fatty liver in rats. J Nutr 134, $522-529$. 
Baba T, Ueda A, Kohno M, Fukui K, Miyazaki C, Hirotsuka M \& Ishinaga M (2004) Effects of soybean beta-conglycinin on body fat ratio and serum lipid levels in healthy volunteers of female university students. J Nutr Sci Vitaminol (Tokyo) 50, 26-31.

Blennemann B, Leahy P, Kim TS \& Freake HC (1995) Tissuespecific regulation of lipogenic mRNAs by thyroid hormone. Mol Cell Endocrinol 110, 1-8.

Cheng SY, Shaw NS, Tsai KS \& Chen CY (2004) The hypoglycemic effects of soy isoflavones on postmenopausal women. J Womens Health (Larchmt) 13, 1080-1086.

Colacurci N, Chiantera A, Fornaro F, de Novellis V, Manzella D, Arciello A, Chiantera V, Improta L \& Paolisso G (2005) Effects of soy isoflavones on endothelial function in healthy postmenopausal women. Menopause 12, 299-307.

Cullen P (2000) Evidence that triglycerides are an independent coronary heart disease risk factor. Am J Cardiol 86, 943-949.

Duranti M, Lovati MR, Dani V, Barbiroli A, Scarafoni A, Castiglioni S, Ponzone C \& Morazzoni P (2004) The alpha' subunit from soybean $7 \mathrm{~S}$ globulin lowers plasma lipids and upregulates liver betaVLDL receptors in rats fed a hypercholesterolemic diet. J Nutr 134, 1334-1339.

Dyck JRB, Kudo N, Barr AJ, Davies SP, Hardie DG \& Lopaschuk GD (1999) Phosphorylation control of cardiac acetyl-CoA carboxylase by cAMP-dependent protein kinase and $5^{\prime}$-AMP activated protein kinase. Eur J Biochem 262, 184-190.

Fukui K, Kojima M, Tachibana N, Kohno M, Takamatsu K, Hirotsuka M \& Kito M (2004a) Effects of soybean beta-conglycinin on hepatic lipid metabolism and fecal lipid excretion in normal adult rats. Biosci Biotechnol Biochem 68, 1153-1155.

Fukui K, Tachibana N, Fukuda Y, Takamatsu K \& Sugano M (2004b) Ethanol washing does not attenuate the hypocholesterolemic potential of soy protein. Nutrition 20, 984-990.

Gardner CD, Newell KA, Cherin R \& Haskell WL (2001) The effect of soy protein with or without isoflavones relative to milk protein on plasma lipids in hypercholesterolemic postmenopausal women. Am J Clin Nutr 73, 728-735.

Greaves KA, Parks JS, Williams JK \& Wagner JD (1999) Intact dietary soy protein, but not adding an isoflavone-rich soy extract to casein, improves plasma lipids in ovariectomized cynomolgus monkeys. J Nutr 129, 1585-1592.

Harwood HJ Jr, Petras SF, Shelly LD, et al. (2003) Isozyme-nonselective $\mathrm{N}$-substituted bipiperidylcarboxamide acetyl-CoA carboxylase inhibitors reduce tissue malonyl-CoA concentrations, inhibit fatty acid synthesis, and increase fatty acid oxidation in cultured cells and in experimental animals. J Biol Chem 278, 37099-37111.

Hermansen K, Sondergaard M, Hoie L, Carstensen M \& Brock B (2001) Beneficial effects of a soy-based dietary supplement on lipid levels and cardiovascular risk markers in type 2 diabetic subjects. Diabetes Care 24, 228-233.

Hillgartner FB, Charron T \& Chesnut KA (1996) Alterations in nutritional status regulate acetyl-CoA carboxylase expression in avian liver by a transcriptional mechanism. Biochem $J$ 319, $\mathrm{Pt} 1$, 263-268.

Huang C \& Freake HC (1998) Thyroid hormone regulates the acetylCoA carboxylase PI promoter. Biochem Biophys Res Commun 249, 704-708.

Huang W, Wood C, L'Abbe MR, Gilani S, Cockell KA \& Xiao CW (2005) Soy protein isolate increases hepatic thyroid hormone receptor content and inhibits its binding to the target genes in rats. J Nutr 135, 1631-1635.

Iritani N, Hosomi H, Fukuda H, Tada K \& Ikeda H (1996) Soybean protein suppresses hepatic lipogenic enzyme gene expression in Wistar fatty rats. J Nutr 126, 380-388.

Iritani N, Nagashima K, Fukuda H, Katsurada A \& Tanaka T (1986) Effects of dietary proteins on lipogenic enzymes in rat liver. $J$ Nutr 116, 190-197.
Katsurada A, Iritani N, Fukuda H, Matsumura Y, Nishimoto N, Noguchi T \& Tanaka T (1990) Effects of nutrients and hormones on transcriptional and post-transcriptional regulation of acetylCoA carboxylase in rat liver. Eur J Biochem 190, 435-441.

Lin Y, Meijer GW, Vermeer MA \& Trautwein EA (2004) Soy protein enhances the cholesterol-lowering effect of plant sterol esters in cholesterol-fed hamsters. J Nutr 134, 143-148.

Meagher EA (2004) Addressing cardiovascular disease in women: focus on dyslipidemia. J Am Board Fam Pract 17, 424-437.

Minokoshi Y, Kim YB, Peroni OD, Fryer LGD, Muller C, Carling D \& Kahn BB (2002) Leptin stimulates fatty-acid oxidation by activating AMP-activated protein kinase. Nature 415, 339-343.

Moriyama T, Kishimoto K, Nagai K, Urade R, Ogawa T, Utsumi S, Maruyama N \& Maebuchi M (2004) Soybean beta-conglycinin diet suppresses serum triglyceride levels in normal and genetically obese mice by induction of beta-oxidation, downregulation of fatty acid synthase, and inhibition of triglyceride absorption. Biosci Biotechnol Biochem 68, 352-359.

Oh SY, Park SK, Kim JW, Ahn YH, Park SW \& Kim KS (2003) AcetylCoA carboxylase beta gene is regulated by sterol regulatory elementbinding protein-1 in liver. J Biol Chem 278, 28410-28417.

Petty KJ, Desvergne B, Mitsuhashi T \& Nikodem VM (1990) Identification of a thyroid hormone response element in the malic enzyme gene. J Biol Chem 265, 7395-7400.

Phipps WR, Wangen KE, Duncan AM, Merz-Demlow BE, Xu X \& Kurzer MS (2001) Lack of effect of isoflavonic phytoestrogen intake on leptin concentrations in premenopausal and postmenopausal women. Fertil Steril 75, 1059-1064.

Potter SM (1998) Soy protein and cardiovascular disease: the impact of bioactive components in soy. Nutr Rev 56, 231-235.

Reeves PG, Nielsen FH \& Fahey GC Jr (1993) AIN-93 purified diets for laboratory rodents: final report of the American Institute of Nutrition ad hoc writing committee on the reformulation of the AIN-76A rodent diet. J Nutr 123, 1939-1951.

Tovar AR, Murguia F, Cruz C, Hernandez-Pando R, Aguilar-Salinas CA, Pedraza-Chaverri J, Correa-Rotter R \& Torres N (2002) A soy protein diet alters hepatic lipid metabolism gene expression and reduces serum lipids and renal fibrogenic cytokines in rats with chronic nephrotic syndrome. J Nutr de Novellis .

Tovar AR, Torre-Villalvazo I, Ochoa M, Elias AL, Ortiz V, AguilarSalinas CA \& Torres N (2005) Soy protein reduces hepatic lipotoxicity in hyperinsulinemic obese Zucker fa/fa rats. J Lipid Res 46, $1823-1832$.

Wakil SJ, Stoops JK \& Joshi VC (1983) Fatty acid synthesis and its regulation. Annu Rev Biochem 52, 537-579.

Wang HJ \& Murphy P (1994) Isoflavone content in commercial soybean foods. J Agric Food Chem 42, 1666-1673.

Wang Y, Jones PJ, Ausman LM \& Lichtenstein AH (2004) Soy protein reduces triglyceride levels and triglyceride fatty acid fractional synthesis rate in hypercholesterolemic subjects. Atherosclerosis 173, 269-275.

Xiao CW, L'Abbe MR, Gilani S, Cooke G, Curran I \& Papademetriou SA (2004) Dietary soy protein isolate and isoflavones modulate hepatic thyroid hormone receptors in rats. J Nutr 134, 743-749.

Xiao CW, Yan X, Li Y, Reddy SA \& Tsang BK (2003) Resistance of human ovarian cancer cells to tumor necrosis factor alpha is a consequence of nuclear factor kappaB-mediated induction of Fasassociated death domain-like interleukin-1beta-converting enzyme-like inhibitory protein. Endocrinology 144, 623-630.

Xiong S, Chirala SS, Hsu MH \& Wakil SJ (1998) Identification of thyroid hormone response elements in the human fatty acid synthase promoter. Proc Natl Acad Sci U S A 95, 12260-12265.

Zhang Y, Yin L \& Hillgartner FB (2001) Thyroid hormone stimulates acetyl-CoA carboxylase-alpha transcription in hepatocytes by modulating the composition of nuclear receptor complexes bound to a thyroid hormone response element. J Biol Chem 276, 974-983. 